https://doi.org/10.52326/jss.utm.2021.4(1).04

UDC 657.3

\title{
THE CONTRIBUTION OF INTEGRATED REPORTING IN DETERMINING THE PERFORMANCE AND VALUE OF A SUSTAINABLE ORGANIZATION
}

\author{
Camelia Mihalciuc*, ORCID ID: 0000-0001-5598-5829 \\ Stefan cel Mare University of Suceava, Suceava, Romania \\ *Corresponding author: Camelia Mihalciuc, cameliamihalciuc@yahoo.com
}

Received: 12. 18. 2020

Accepted: 01. 28. 2021

\begin{abstract}
In the current business environment, financial reporting has become insufficient in terms of information, which is caused by the increasing information needs of stakeholders. In this context, an integrated reporting modality has emerged thanks to the International Integrated Reporting Council (IIRC), where the information presented is both financial and nonfinancial information, such reporting being called "Integrated Reporting". Thus, starting from this consideration, the main objective of the paper aims at the main aspects that lead to the presentation of the benefits of implementing integrated reporting in organizations, through the ability to understand, in a more complete way, the "real" performance of a sustainable organization. The essential elements contained in an integrated reporting concern the capital, the business model and the process of creating and maintaining value, this reporting must be integrated in the strategy and vision of the organization, allowing through the transparency of these integrated reports the observation of all aspects led to the results obtained by the organization, as well as providing information on the role of the organization in society and the context in which it operates, the image of the organization being complete. The purpose of this paper is to highlight the importance and role assigned to integrated reporting in measuring the performance of a sustainable organization, by making it easier to understand the cause and effect of the link between financial performance and sustainability by stakeholders.
\end{abstract}

Keywords: sustainable organization, financial reporting, non-financial reporting, corporate reporting, value creation, business model, real performance.

Rezumat. În actualul mediu de afaceri, raportarea financiară a devenit insuficientă din punct de vedere informational, cauzate de nevoile informaționale tot mai mari ale părților interesate. În acest context, a apărut o modalitate de raportare integrată grație Consiliului internațional de raportare integrată (IIRC), în care informațiile prezentate sunt atât informații financiare, cât și non-financiare, astfel de raportare numindu-se „Raportare integrată”. Deci, pornind de la această considerație, obiectivul principal al lucrării vizează principalele aspecte care conduc la prezentarea beneficiilor implementării raportării integrate în organizații, prin capacitatea de a înțelege, într-un mod mai complet, performanța „reală”, a unei organizații sustenabile. Elementele esențiale conținute într-o raportare integrată privesc capitalul, modelul de afaceri și procesul de creare și menținere a valorii, această raportare trebuind integrată în strategia și viziunea organizației, permițând prin transparența acestor rapoarte integrate observarea tuturor aspectelor ce au condus la rezultatele obținute de organizație, precum și furnizarea de informații cu privire la rolul organizației în societate și contextul în care operează, imaginea organizației 
fiind completă. Scopul acestei lucrări este de a evidenția importanța și rolul atribuit raportării integrate în măsurarea performanței unei organizații durabile, facilitând înțelegerea cauzei și efectului legăturii dintre performanța financiară și sustenabilitate de către părțile interesate.

Cuvinte cheie: organizaţie sustenabilă, raportare financiară, raportare nefinanciară, raportare corporativă, creare de valoare, model de afaceri, performanță reală.

\section{Introduction}

The management of an organization has an essential role in implementing the concept of integrated reporting because its decisions can lead to the understanding and correct implementation or not of such reporting, exceeding the declarative level and also improving the activity of the organization [1]. Currently, organizations are determined to "think" in an integrated way, ie, the more they will use an integrated approach to their business, the more will justify the application of the concept of information connectivity in managerial reporting, analysis and decision-making [2]. Many studies presented in the literature on organizations that apply integrated reporting and implement sustainability principles in business development showed the causal relationship that exists between integrated reporting, sustainability and stakeholder interests [3 - 6].

At present, where the existence of a social responsibility is required, there is a need to determine the non-financial performance (social and environmental), which must be found as information, indirectly, but in an obvious concordance and in the financial statements of those entities [7]. Basically, profit maximization and increasing market share are the main objectives of organizations, but they must be joined by other objectives that take into account the effects of business decisions on stakeholders [8].

In the global economic context, where the situation of organizations can change 360 degrees from day to day and where the uncertainty of tomorrow is a concern facing a multitude of people, investors need information to provide them as much as possible much confidence in the continuity of the organization, its productivity and the ability to cope with all obstacles, always achieving positive results [9]. Financial information is no longer sufficient to meet the information needs of investors, so organizations have moved to a tool that includes both financial and social information, environmental information, strategy, opportunities and risks, as is integrated reporting [10].

\section{The concept of integrated reporting of a sustainable organization}

Corporate sustainability has been presented in the literature as representing the ultimate goal of organizations, by meeting the needs of the present without compromising the ability of future generations to meet their own needs [11]. We note that the three aspects of sustainability (economic, environmental and social) are translated into an approach to corporate sustainability [12]. Socially responsible companies have highlighted in their financial statements specific elements to be followed by all categories of stackeholders [13]. The shift to corporate responsibility in business practice is a response not only to the negative environmental effects that the organization can have, but also to assessing the economic and social effects of the organization on a global scale, long-term corporate sustainability emphasizing the impact on an organization. from an environmental, economic and social point of view as well as their interactive effect [14].

Non-financial reporting has taken many forms in addition to the inclusion of non-financial information in the annual reports under the heading of social responsibility reports, environmental balance sheet, social balance sheet, corporate governance report or sustainability report, but they have not been sufficient to keep pace with changes in the world economy and with the desire to achieve a sustainable economy [15]. 
The International Council on Integrated Reporting (IIRC) defines integrated reporting as follows: "Integrated reporting is a process founded on integrated thinking that results in a periodic integrated report by an organization about value creation over time and related communications regarding aspects of value creation" [16].

Integrated reporting is thus a set of processes and activities that allow the integration of corporate reporting and the development of communication of financial, environmental and social performance through a single annual report, which provides an overview of the organization's ability to create value responsibly and efficiently, addressing all stakeholders in a comprehensive, clear, concise and comparable manner [17].

Integrated reporting is not additional reporting, prepared and published in addition to existing ones, but is a new approach to financial reporting that includes issues related to strategy, financial performance and the social, environmental and economic context in which the organization operates [18]. Eccles and Serafeim (2011) state that integrated reporting focuses on the process of creating value for all stakeholders in the medium and long term through a single report accessible to all stakeholders that shows how social and environmental performance together with good governance contributes to a high financial performance [19].

\section{The evolution of integrated reporting}

The concept of integrated reporting has evolved both theoretically and in the practice of organizations around the world. Integrated reporting has its origins in two main ideas that began to circulate in the mid-1990s [6].

The first idea starts from the premise that organizations should supplement the reported financial information with other relevant non-financial information, the motivation being the inability to obtain a complete picture of the organization's performance.

According to the second idea, stakeholders are not only shareholders, for this reason, the reporting should also take into account those environmental, social and governance issues that, although not relevant to shareholders, nevertheless draw attention and the interest of a multitude of people. To materialize the last idea, the first steps were taken in 1997 by Robert K. Massie and Allen L. White [8], by setting up the non-profit organization Global Reporting Initiative (GRI), with the aim of creating an accountability mechanism to ensure compliance with CERES principles (Sustainable Use of Natural Resources, Protection of the Biosphere, Reduction and Disposal of Wastes Energy Conservation, Risk Reduction, Safe Products and Services, Envirnmental Restoration, Informing the Public, Management Commitment, Audits and Reports) for environmentally responsible behavior [20].

The late 1990s are characterized by a growing interest in the performance of ESG (Environmental, Social and Corporate Governance), with financial performance becoming insufficient in terms of the information provided [4]. In 2002, the Danish bio-industry Novozymes published its first integrated report. Two years later, the pharmaceutical company Novo Nordisk also published a report containing both financial and non-financial information. The Canadian cooperative Vancity, although measuring and reporting social and environmental performance since 1997, only in 2005 began a process of integrating aspects of strategy, planning, risk management, performance reporting and financial information. In 2005 White wrote about "integrated, balanced and honest reporting" in Danish [21]. In 2010, 1861 companies issued sustainability reports using the "G3 guidelines" of the non-profit organization GRI.

The first American company to publish an integrated report was United Technolohies Corporation, in 2008. A year later, South Africa published the King III Corporate Governance Code, which recommended that organizations publish integrated reports. This provision shall apply to companies listed on the Johannesburg Stock Exchange as of March 1, 2010 [22]. 
In 2009, the British organization "The Prince of Wales" convened a high-level meeting of investors, companies, accountants, standardizers and UN representatives, including IFAC and GRI, to establish the International Integrated Reporting Committee (IIRC), renamed in 2011 the International Integrated Reporting Council, as a body to deal with the creation of a globally accepted integrated reporting framework, this international body must bring together organizations with relevant experience and recognition in the fields of transparency, accounting and financial reporting. The purpose of this meeting was, as we specified, the development of a conceptual framework on integrated reporting (financial and non-financial), as a first step in the process of achieving a sustainable economy [23]. IIRC developed the Conceptual Framework on Integrated Voluntary Reporting in 2013 and argues that integrated reporting promotes a more coherent and effective approach to corporate reporting and aims to improve the quality of information available to financial capital providers to enable more efficient capital allocation [24]. IIRC's long-term vision is a world in which the concept of integrated thinking is implemented in business practices in the public and private sectors so that integrated reporting has become a norm of corporate reporting [25], and communication resulting from reporting. The main purpose of the Integrated Fund is to support long-term investor decisions on the allocation of financial capital, aiming to align the public interest in the long term, as well as the creation and maintenance of short- and medium-term value [26]

\section{Integrated reporting - business model of a sustainable organization}

The global economic crisis has not only affected the economy but also affected corporate reporting, with organizations around the world realizing that they need to change the way they do business, so traditional financial reporting has been overtaken by the new approach to business sustainability and information requirements of the stakeholders [27].

The business model is a system of inputs, value-added activities and outputs, which aim to create and maintain value in the short, medium and long term [26]. Sustainable business models (SBM) [9] incorporate a threefold approach and consider a wider range of stakeholder interests, including the environment and society. Sustainable business model archetypes are introduced to describe clusters of mechanisms and solutions that can contribute to building the business model for sustainability [26]. The main purpose of integrated reporting is to explain to capital providers how an organization creates value over time, taking into account all available information, whether financial or non-financial. According to the IIRC, the best way to do this is through a combination of qualitative and quantitative information that takes the form of the six capitals: financial, productive, intellectual, human, social and relational, as well as natural [28].

Capitals are valuable structures that are affected and transformed by the activities of the organization. However, organizations are not required to pursue this division in their own integrated reports. The integrated report aims to illustrate the ways in which an organization interacts with the external environment and what capital is used to create value in the short, medium and long term. The ability of an organization to create value for itself allows capital providers to achieve an economic return, this ability being associated with value created by the organization for stakeholders and society, through a wide range of activities, relationships and interactions. When the latter significantly affect the organization's ability to create value, they are included in the integrated report [29].

The international framework of integrated reporting adopts an approach based on the objective of these principles, consisting in achieving a balance between flexibility and requirements, so as to analyze the many variations introduced by the specific circumstances of a single organization and, at the same time, ensure a level of comparability between organizations sufficient to meet the relevant information needs. Thus, in the elaboration of the integrated report the principles presented in figure no. 1 must be based: 


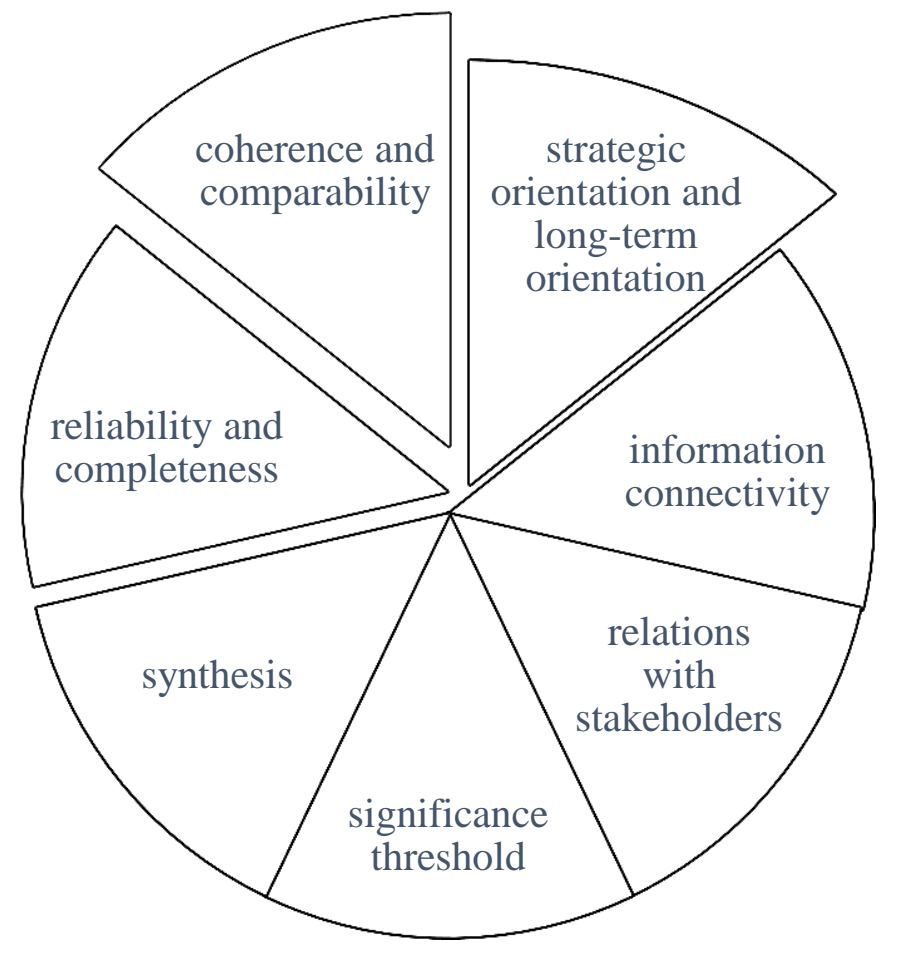

Figure 1. Integrated report compilation principles.

Source: Own processing based on: https://integratedreporting.org

In accordance with these principles, an integrated report should provide detailed information on the organisation's strategy and how this strategy affects both the ability to create value and the use of capital and its effects on capital; it should provide a complete picture of the links and dependencies between the factors that influence the organisation's ability to create value over time; it should provide detailed information on the nature and quality of the organisation's relations with stakeholders and the extent to which the organization responds to their needs and interests; should provide information on issues that significantly affect the organization's ability to create value over time; it should be concise and contain all material issues; all the information contained in the report should be useful, consistent, in a format that allows comparison with other organizations [28].

From all these stated characteristics we can say that an integrated report benefits all stakeholders in the organization's ability to create value over time, including employees, customers, suppliers, business partners, local communities and legislators. Thus, there are a multitude of benefits associated with integrated reporting for both the organization itself and stakeholders, and a concise presentation of the content and benefits of such a report can be presented in Table 1.

Table 1

The content and benefits of an integrated report

\begin{tabular}{ll}
\hline The content of an integrated report & The benefits of an integrated report \\
\hline $\begin{array}{l}\text { A presentation of the organization and the } \\
\text { external environment }\end{array}$ & $\begin{array}{l}\text { Encourage the organization to think in an } \\
\text { integrated way }\end{array}$ \\
$\begin{array}{l}\text { The way the organization supports its ability } \\
\text { to create value in the short, medium and }\end{array}$ & $\begin{array}{l}\text { All information is contained in a single } \\
\text { report }\end{array}$ \\
$\begin{array}{ll}\text { long term business model of the organization } & \text { It allows easier identification of risks and } \\
& \text { opportunities }\end{array}$ \\
\hline
\end{tabular}




\begin{tabular}{|c|c|}
\hline & Cont \\
\hline Risks and opportunities & $\begin{array}{l}\text { Allows identification of all factors that have } \\
\text { contributed to the performance of the } \\
\text { organization and easier identification of } \\
\text { risks and opportunities }\end{array}$ \\
\hline Strategy and method of resource allocation & $\begin{array}{l}\text { Develops a clearer link between strategy, } \\
\text { materiality, performance indicators and risk }\end{array}$ \\
\hline $\begin{array}{l}\text { The extent to which the organization has } \\
\text { achieved its strategic objectives }\end{array}$ & Improves information connectivity \\
\hline $\begin{array}{l}\text { The challenges and uncertainties that the } \\
\text { organization may face in implementing its } \\
\text { strategy }\end{array}$ & $\begin{array}{l}\text { It demonstrates the value that an } \\
\text { organization creates for society and for } \\
\text { itself }\end{array}$ \\
\hline \multirow{2}{*}{$\begin{array}{l}\text { How the organization chooses which aspects } \\
\text { to include in the integrated report and how } \\
\text { they are evaluated and quantified }\end{array}$} & Provides more complete information \\
\hline & $\begin{array}{l}\text { Allows a better analysis of economic, social } \\
\text { and environmental issues, relevant to } \\
\text { improving their financial performance } \\
\text { Improves stakeholder involvement } \\
\text { Strengthens trust with different interest } \\
\text { groups }\end{array}$ \\
\hline
\end{tabular}

Source: Own processing based on [10] [30-31]

Despite the many benefits, there are people who do not recommend the development of the integrated report, criticizing in particular the international framework developed by the IIRC, saying that the interest is more in the value for investors to the detriment of other categories of stakeholders. The report also contains a wealth of information, sometimes even unnecessary, lacking the ability to make a clear distinction between information that influences the value of the organization and that does not influence [32], and the risk of disclosure of information is given by increased costs corporate reporting [33].

\section{Country analysis of integrated reporting organizations}

Today a number of organizations from different countries and fields publish integrated reports. The situation in the period 2013-2017 regarding the number of reporting organizations and the number of integrated reports can be seen in Table 2.

Table 2

Integrated reporting in the world

\begin{tabular}{cc}
\hline Country & $\begin{array}{c}\text { Number of integrated reports from total } \\
\text { reporting organizations }\end{array}$ \\
\hline Argentina & $9 / 4$ \\
Australia & $64 / 23$ \\
Austria & $17 / 8$ \\
Bangladesh & $3 / 3$ \\
Belgium & $15 / 5$ \\
Botswana & $4 / 1$ \\
Brazil & $147 / 58$ \\
Bulgaria & $3 / 1$ \\
Canada & $20 / 9$ \\
Chile & $25 / 17$ \\
\hline
\end{tabular}




\begin{tabular}{|c|c|}
\hline China & $3 / 2$ \\
\hline Colombia & $33 / 15$ \\
\hline Costa rica & $1 / 1$ \\
\hline Croatia & $1 / 1$ \\
\hline Cyprus & $3 / 2$ \\
\hline Czech republic & $1 / 1$ \\
\hline Denmark & $8 / 2$ \\
\hline Finland & $24 / 15$ \\
\hline France & $89 / 44$ \\
\hline Germany & $26 / 8$ \\
\hline Greece & $17 / 5$ \\
\hline Hungary & $1 / 1$ \\
\hline Iceland & $1 / 1$ \\
\hline India & $44 / 29$ \\
\hline Indonesia & $7 / 4$ \\
\hline Ireland & $1 / 1$ \\
\hline Israel & $1 / 1$ \\
\hline Italy & $105 / 38$ \\
\hline Japan & $374 / 162$ \\
\hline Jordan & $1 / 1$ \\
\hline Kenya & $13 / 4$ \\
\hline Lebanon & $1 / 1$ \\
\hline Malaysia & $32 / 20$ \\
\hline Mauritius & $20 / 9$ \\
\hline Mexico & $7 / 6$ \\
\hline Nigeria & $1 / 1$ \\
\hline Namibia & $6 / 4$ \\
\hline Norway & $10 / 6$ \\
\hline Pakistan & $7 / 5$ \\
\hline Peru & $4 / 2$ \\
\hline Philippines & $11 / 7$ \\
\hline Poland & $25 / 10$ \\
\hline Portugal & $10 / 7$ \\
\hline Republic of Korea & $91 / 33$ \\
\hline Russian federation & $64 / 22$ \\
\hline Saudi arabia & $6 / 3$ \\
\hline Serbia & $1 / 1$ \\
\hline Slovenia & $3 / 2$ \\
\hline South africa & $939 / 243$ \\
\hline Spain & $168 / 61$ \\
\hline Sri Lanka & $195 / 65$ \\
\hline Sweden & $34 / 22$ \\
\hline Swaziland & $6 / 2$ \\
\hline Switzerland & $20 / 9$ \\
\hline Uganda & $2 / 1$ \\
\hline UK & $82 / 37$ \\
\hline Ukraine & $2 / 2$ \\
\hline United Arab Emirates & $4 / 3$ \\
\hline
\end{tabular}




\begin{tabular}{cc}
\hline USA & $61 / 30$ \\
Qatar & $7 / 4$ \\
Thailand & $12 / 5$ \\
Taiwan & $24 / 13$ \\
The netherlands & $148 / 63$ \\
Turkey & $19 / 9$ \\
Zimbabwe & $3 / 3$ \\
\hline
\end{tabular}

Source: Own processing based on [34]

A top of the first 10 countries in which we find the most organizations that prepare integrated reports can be viewed in figure no. 2 .

As can be seen from table number 2 and the graphical representation in Figure no. 2, the main reporting countries (according to the number of published reports) are South Africa (939), Japan (374), Sri Lanka (195), Spain (168), the Netherlands (148), Brazil (147) and Italy (105). However, South Africa and Japan alone have over 100 reporting organizations.

South Africa's supremacy can be considered to have its origins in the publication of the King III Corporate Governance Code in 2009, which recommended that companies prepare an integrated report that reflects an organisation's strategy, risks, performance and sustainability.

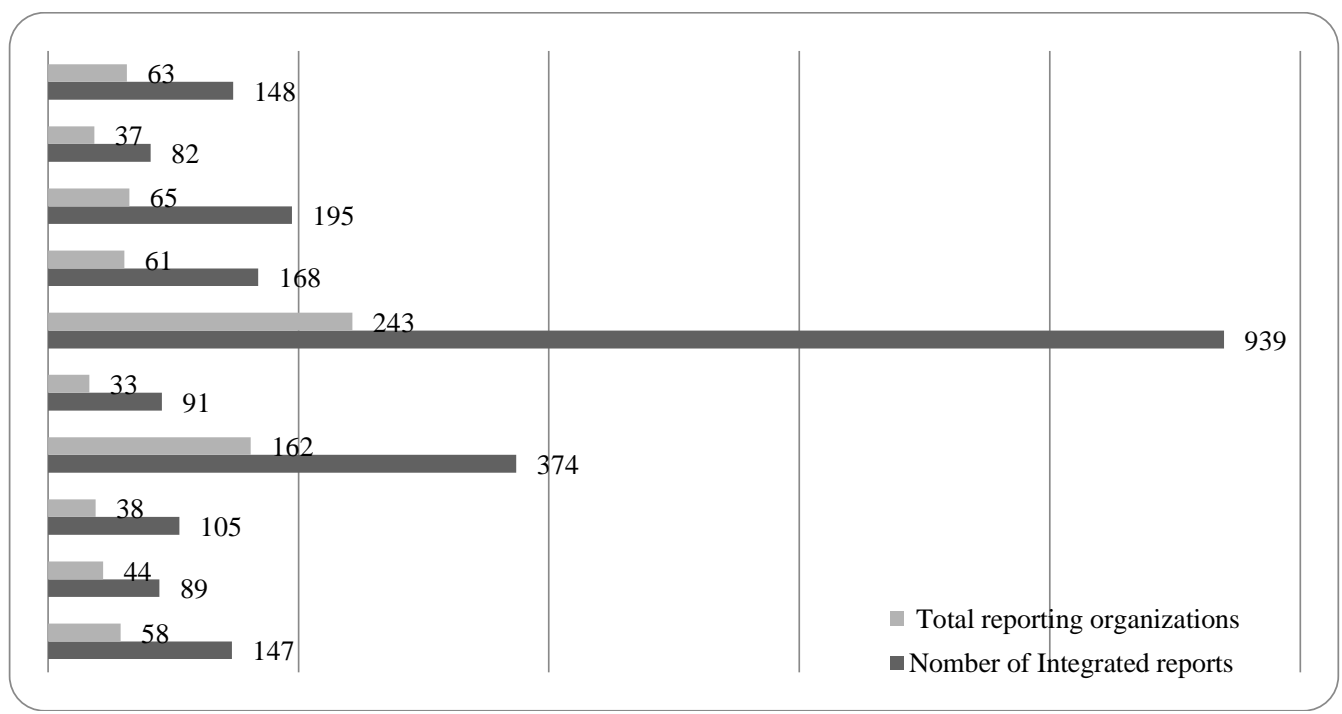

Figure 2. Top 10 countries by number of reporting organizations and number of integrated reports prepared.

Source: Own processing based on the data in Table 2.

However, as the principles of the code were later included in the listing requirements of the Johannesburg Stock Exchange (JSE), listed companies were required to prepare the integrated reports [5]. Today, integrated reporting is a common practice that has spread even in the public and non-profit sectors. South African organizations follow the best practice guidelines of the framework in line with the general principles of corporate governance and the practices recommended by the new governance code, King IV.

According to a report published by KPMG, in 2018 there were 414 integrated reports declared by Japanese companies. Compared to previous periods, there has been an increase in the number of published reports in Japan, most of which come from large companies. Of the 2,218 organizations in the first section of the Tokyo Stock Exchange, 382 issued integrated reports [34]. 
From the analysis of the data presented of the number of integrated reports in each country, Japan is clearly one of the leading countries in the world for voluntary integrated reporting. The situations between the two countries are completely opposite, one being obliged to draw up integrated reports and the other reporting voluntarily. However, both are in the first place when it comes to integrated reporting, which shows that the implementation method is not relevant. Instead, the results are visible, with the number of reporting organizations increasing. Romania currently has no companies to prepare integrated reports, however there are many organizations that prepare both financial and non-financial reports, such as sustainability reports, among them Electrica and Antibiotice SA.

\section{Use of integrated reporting as a tool to communicate financial and non-financial performance to stakeholders}

Recently, large corporations present their business in a more transparent and accountable manner [31]. Thus, in order for businesses to be able to fulfill their obligations in accordance with the ethics of stakeholder responsibility, they must provide relevant, timely and intelligible information about their activities through corporate reports. The organisation's conventional reports on annual financial performance, sustainability and governance disclosures often fail to link the organisation's strategy, financial results and environmental, social and governance performance. Recognizing the inherent shortcomings of existing reporting models, there is a growing trend towards integrated reporting [21].

According to GRI (Global Reporting Initiative), sustainability reporting is the practice of measuring, disclosing and being accountable to internal and external stakeholders in terms of organizational performance to achieve the goal of sustainable development. A sustainability report should provide a balanced and reasonable representation of the sustainability performance of the reporting organization, including positive and negative contributions [35].

With integrated reporting, stakeholders in the organization's situation can better understand the cause and effect of the links between financial performance and sustainability. The transparency of the integrated reports allows the observation of all aspects that led to the results obtained by the organization. In addition, this report provides information on the role of the organization in society and the context in which it operates, the image of the organization presented in the report being complete, taking into account all aspects that influenced the management of the activity and performance.

The integrated report communicates to stakeholders all information on its performance, whether good or bad, also creates commitments to improve future performance and establishes responsibility for meeting the objectives, and the dependencies between financial and nonfinancial performance are highlighted in this report. Those who prepare strictly financial annual reports provide only a financial picture of performance, which is insufficient in a qualitative decision-making process. The integrated reports help to complete the financial report with that information that allows obtaining a complete vision on the real performance of the organization [36-37]. Integrated reporting is a new practice that is more comprehensive on the one hand, as it takes into account the many information needs of stakeholders, and, on the other hand, brings together financial and non-financial factors in a single report, providing the possibility to determine easier and more relevant to the value of the organization and performance [37].

Moreover, reports on annual financial performance, sustainability and governance disclosure often fail to link the organisation's strategy, financial performance and environmental, social and governance performance. In this context of shortcomings in existing reporting models, integrated reporting has emerged as a preferred approach [31-33], as "a holistic and integrated representation of the organization's performance in terms of both funding and sustainability". In general, the integrated reporting activity aims to combine two traditional forms of corporate 
reporting - financial reporting and sustainability - to compensate for the identified inadequacies of previous corporate reporting procedures [21].

An overview of the organization's performance can be seen even without integrated reporting in the annual report prepared by most organizations. However, this image is often incomplete, as the performance of the organization may be the result of factors other than financial. An example can be the situation of an organization that has registered positive results due to the employment of a large number of people with higher education who have made a significant contribution in production techniques and methods of work organization [35-36]. Such information would provide a different picture of the performance of organizations and could lead to the emergence of employee training programs or even the creation of facilities for employees who are engaged in higher education. This type of information is presented in the integrated reports.

The study by García-Sánchez et al. (2018) aimed to analyze whether the trend towards integrated reporting depends on management and whether this relationship is influenced by internal control mechanisms (eg board of directors) or external (level of investor protection) [28]. The study of the impact of the transition from sustainable reporting to integrated reporting on non-financial disclosure of eight South African companies using the analysis of the content of annual reports was conducted by Clayton, et al, in 2015, the purpose of this study is to review the development of integrated reporting corporations in South Africa.

Loprevite et al. (2018) present in their study the link between integrated reporting and integrated performance (financial, social, environmental and governance), the authors concluding that voluntary regimes, integrated performance levels achieved by organizations are higher levels and integrated performance shows significant improvements in the years of mandatory adoption of integrated reporting, with intensifying effects in the medium term. A positive example in this situation is South Africa where integrated reporting has become mandatory since 2010 for publicly listed companies.

Most studies found in the literature focus on factors that influence organizations' decision to adopt integrated reporting, on the compliance of reports published by organizations with the international reporting framework under the IIRC, on the credibility or asymmetry of information in integrated reports, but there are fewer related studies the integrated performance of an organization or other perspectives of financial implications [36].

Integrated reporting provides an overview of the performance of the organization, which is described both financially and from other points of view considered non-financial but relevant to the full understanding of the real situation [34]. This report describes to users the resources and relationships that underlie value creation and which are used to preserve value in the short, medium and long term [37,38]. Overall, all the data in this report aims to provide a transparent presentation of how the organization is managed, the results and the actual performance, so that investors are helped to manage risks and allocate resources as efficiently as possible.

\section{Conclusions}

Integrated reporting gives stakeholders the opportunity to evaluate the organization from all points of view, whether financial or economic, environmental or social performance, thus facilitating the decision-making process, and the full picture provided by the report facilitates the measurement of the organization's capacity to create long-term value. The performance image provided by integrated reporting is useful for all categories of users as it takes into account the diversity of information needs and the diversity of the interests of the parties.

In conclusion, integrated reporting has a very important role in measuring performance as it offers the possibility to understand all the factors that were the basis of the process of 
creating the value of the company, respectively the factors that determined its achievement. Thanks to the integrated report, performance is observed from all angles and the decisionmaking process is simplified and much more relevant.

In order for an organization to fulfill its obligations in accordance with the ethics of responsibility, it is important that stakeholders are provided with relevant, timely and easy-tounderstand information about their activities. We can strongly argue that integrated reporting must be implemented in the entire activity of an organization through the concept of integrated thinking so as to influence not only the way of reporting but also its results. Adopting integrated reporting can be useful in increasing financial performance and strengthening the relationship with stakeholders if used properly overcoming the barrier of being a simple management policy adopted to respond to external pressure from stakeholders and the international market.

\section{References}

1. Esch M., Schnellbacher B. and Walt A. (2019). Does integrated reporting information influence internal decision making? An experimental study of investment behavior. Business Strategy And The Environment. 1-12. DOI: 10.1002/bse. 2267.

2. Fasan M. and Mio C. (2016). Fostering Stakeholder Engagement: The Role of Materiality Disclosure in Integrated Reporting. Business Strategy And The Environment. 26(3), pp. 288-305. Retrieved from https://doi.org/10.1002/bse.1917.

3. Bratu A. (2017). Empricial study regarding the integrated reporting practices in Europe. Financial Audit Magazine, vol. XV, 4(148)/2017, pp. 613-627, DOI: 10.20869/AUDITF/2017/148/613.

4. Cheng M., Green W., Romi A. and Konishi N. (2014). The International Integrated Reporting Framework: Key Issues and Future Research Opportunities. Journal of International Financial Management and Accounting. Retrieved from: http://onlinelibrary.wiley.com/doi/10.1111/jifm.12015/epdf.

5. Clayton F. A., Rogerson M.J and Rampedi I. (2015). Integreted reporting vs. sustainability reporting for corporate responsability in South Africa. Bulletin of Geography. Socio-economic Series, no. 29, pp. 7-17, Nicolaus Copernicus University. Retrieved from: http://www.bulletinofgeography. umk.pl/29_2015/01_Clayton.pdf; DOI: http://dx.doi.org/10.1515/bog-2015-0021

6. Eccles G. R. and Armbrester K. (2011). Two disruptive ideas combined: Integrated Reporting in the Cloud, IESE Insight. No. 8/2011. Retrieved from: http://www.people.hbs.edu/reccles/Insight_Article_2011.pdf.

7. Cavezzali E. (2013). Il report integrato Nuovo strumento per comunicare informazioni sulla creazione di valore, Tesi di Laurea. Retrived from: http://dspace.unive.it/bitstream/handle/10579/4346/8398811173496.pdf?sequence=2\&fbclid=IwAR0yfLpg8QD_ohBHdmKxpc1UJa95UN-HwUzH5MbUYVXxttzoyWhS5cztSe0.

8. García-Sánchez I. M. and Noguera-Gámez L. (2017). Integrated information and the cost of capital. International Business Review. 26(5), pp. 959-975. Retrieved from DOI: http://dx.doi.org/10.1016/j.ibusrev.2017.03.004.

9. García-Sánchez I. M., Martinez-Ferrero J. and Garcia-Benau M.-A. (2018). Integreted reporting: The mediating role of the board of directors and investor protection on managerial discretion in munificent enviroments. Corporate Social Responsibility And Environmental Management. 26(1), pp. 29-45. DOI: 10.1002/csr.1665.

10. Bocken N.M.P, Short S.W., Rana P., Evans S. (2014). A literature and practice review to develop sustainable business model archetypes, Journal of Cleaner Production, Volume 65, 15 February 2014, pp. 42-56. Retrieved from: https://doi.org/10.1016/j.jclepro.2013.11.039.

11. Thomsen C. 2013: Sustainability (World Commission on Environment and Development Definition). In: Idowu, S.O., Capaldi, N., Zu, L. and Das Gupta, A. editors, Encyclopedia of Corporate Social Responsibility, Heidelberg: Springer, pp. 2358-2363.

12. Jonikas D. 2013: Conceptual Framework of Value Creation through CSR in a Separate Member of Value Creation Chain. In: Szymańska, D. and Chodkowska-Miszczuk, J. editors, Bulletin of Geography: Socio Economic Series, Vol. 21, Toruń: Nicolaus Copernicus University Press, pp. 69-78. Retrieved from DOI: http://dx.doi. org/10.2478/bog2013-0022.

13. Loprevite S., Ricca B. and Rupo D. (2018). Performance Sustainability and Integrated Reporting: Empirical Evidence from Mandatory and Voluntary Adoption Contexts. Sustainability, 10(5). Retrieved from DOI: https://doi.org/10.3390/su10051351.

14. White G.B. 2009: Sustainability Reporting: Managing for Wealth and Corporate Health, New York: Business Expert Press.

15. Turk B.K., Shackleton C.M. and Whittington-Jones L., 2013: Prevalence of Sustainability Reporting Practices of a Sample of Listed Companies on Established and Emerging Stock Exchanges. In: South African Journal of Economic and Management Sciences, Vol. 16(1), pp. 75-82.

16. Integrated Reporting.org, disponibil la adresa: https://integratedreporting.org 
17. Katsikas E., Rossi F. M., Orelli L. R. (2017). Towards Integrated Reporting-Accounting Change in the Public Sector, Springer International Publishing AG, Switzerland.

18. Eccles G. R., Krzus P. M. (2010). One Report. Integrated Reporting for a Sustainable Strategy, John Wiley and Sons, Inc., Hoboken, New Jersey.

19. Eccles R. G. and Serafeim G. (2011). Accelerating the Adoption of Integrated Reporting. CSR INDEX. Francesco de Leo, Matthias Vollbracht, eds., InnoVatio Publishing Ltd., Beirut Boston Pretoria Tianjin Zurich. Retrieved from: https://papers.ssrn.com/sol3/papers.cfm?abstract_id=1910965.

20. GRI Standards (Global Reporting Initiative) (2011). Retrived from: https://www.globalreporting.org/ standards/

21. White A.L., 2010: Toward a Holistic Architecture for Corporate Disclosure. In: Eccles, R.G., Cheng, B. and Saltzman, D. editors, The Landscape of Integrated Reporting: Reflections and Next Steps, Boston: Harvard Business School, pp. 29-32.

22. Steenkamp N. (2018). Top ten South African companies' disclosure of materiality determination process and material issues in integrated reports. Journal Of Intellectual Capital, 19(2), pp. 230-247. Retrieved from: DOI: https://doi.org/10.1108/JIC-01-2017-0002.

23. Integrated reporting.org, When advocate for global adoption/find out what is happening in your region? Find what is happening in your region. Retrived from: https://integratedreporting.org/when-advocate-for-globaladoption/find-out-what-is-happening-in-your-region/

24. Integrated Reporting.org, The international ir framework Italian. Retrived from: https://integratedreporting.org/wp-content/uploads/2015/03/13-12-08-THE-INTERNATIONAL-IR-FRAMEWORKItalian.pdf

25. Integrated Reporting, What the tool for better reporting/get to grips with the six capitals. Retrived from: https://integratedreporting.org/what-the-tool-for-better-reporting/get-to-grips-with-the-six-capitals/

26. Botez D. (2013). Raportarea integrată - sfârșit sau un nou început pentru raportarea financiară?. Financial Audit Magazine, 98 (2), pp. 25-29. Retrieved from: https://www.cafr.ro/uploads/AF\%202\%202013\%20-\%20Sitefb56.pdf.

27. KMPG. (2017). The KPMG Survey of Corporate Responsibility Reporting 2017. Retrieved from: https://assets.kpmg/content/dam/kpmg/xx/pdf/2017/10/kpmg-survey-of-corporate-responsibility-reporting2017.pdf

28. IIRC. (2013). The International IR Framework. Retrieved from: http://integratedreporting.org/wpcontent/uploads/2015/03/13-12-08-the-international-ir-framework-2-1.pdf

29. Bray M. (2013). What does an Integrated Report look like? KPMG in Australia and Matt Chapman, KPMG in the UK, KPMG International. Retrieved from: https://home.kpmg/content/dam/kpmg/pdf/2013/04/what-does-irlook-like.pdf?fbclid=IwAR22L PsEEFMu-RqJKpRg8nc3qKm_eXG6TTuhFMNsf_ZRgA5B_MWDi8 SsnrM

30. Busco C., Frigo M. L., Quattrone P. and Riccaboni A. (2013). Towards Integrated Reporting: Concepts, Elements and Principles. from Integrated Reporting Concepts and Cases that Redefi ne Corporate Accountability. Editors Busco C., Frigo M. L., Quattrone P. and Riccaboni A. Springer International Publishing Switzerland.

31. Mio C. (2016). Integrated Reporting. A New Accounting Disclosure. From Integrated Reporting: The IIRC Framework. Editor Mio, C., Springer, London.

32. García-Sánchez I. M., Frias-Aceituno J. V. and Rodriguez-Ariza L. (2013). The cultural system and integrated reporting. International Business Review, 22(5), pp. 828-838, Retrieved from DOI:https://doi.org/10.1016/j.ibusrev.2013.01.007.

33. Eccles G. R., Krzus M. P. and Ribot S. (2015). The Integrated Reporting-Movement, Meaning, Momentum, Motives, and Materiality, Wiley and Sons, Inc., Hoboken, New Jersey.

34. Vitolla F., Raimo N. and Rubino M. (2019). Apreciations, criticisms, determinants and effects of integrated reporting: A systematic literature review. Corporate Social Responsibility And Environmental Management. 26(2), pp. 518-528. DOI: 10.1002/csr.1734.

35. Ball R. (2001). Infrastructure Requirements for an Economically Efficient System of Public Financial Reporting and Disclosure, Brookings-Wharton Papers on Financial Services, Brookings Institution Press, pp. 127-169. Retrived from: https://muse.jhu.edu/article/266291.

36. Eccles B. (2019). What is the world can lear from the japanese experience in integrated reporting, Retrived from: https://www.forbes.com/sites/bobeccles/2019/07/09/what-the-world-can-learn-from-the-japanese-experiencein-integrated-reporting/\#7b6cb0586fcb.

37. García-Sánchez I. M. and Noguera-Gámez L. (2016). Integrated Reporting and Stakeholder Engagement: The Effect on Information Asymmetry. Corporate Social Responsibility And Environmental Management. 24(5), pp. 395-413, DOI: 10.1002/csr.1415.

38. García-Sánchez I. M. and Noguera-Gámez L. (2017). Integrated information and the cost of capital. International Business Review. 26(5), pp. 959-975. Retrieved from DOI: http://dx.doi.org/10.1016/j.ibusrev.2017.03.004. 